\title{
External Morphology of the Adult of Heraclides anchisiades capys (Hübner, [1809]) (Lepidoptera - Papilionidae) II. Thorax and thoracic appendages
}

\author{
Luis Anderson Ribeiro Leite ${ }^{*}$, Mirna Martins Casagrande and Olaf Hermann Hendrik \\ Mielke \\ Departamento de Zoologia; Setor de Ciências Biológicas; Universidade Federal do Paraná; C. P.: 19020; 81531 - \\ 980; Curitiba - PR - Brasil
}

\begin{abstract}
The purpose of this study was to highlight the morphological components of the thorax and its appendages of the adults of Heraclides anchisiades capys (Hübner, [1809]), seeking a comparative focus with other Papilionoidea and Hesperioidea. The morphology was studied using illustrations and scanning electronic microscope. The most relevant morphological characters were: membranous patagia on prothorax; anepisternum II fused with the pleural wing process II as a small sclerite dorsal to the katepisternum II; 3A present on the forewing, reaching the inner margin on its proximal third; presence of basalare III "pad" and meral suture on coxa III.
\end{abstract}

Key words: Citrus, Neotropical, Papilioninae, Papilionoidea

\section{INTRODUCTION}

The thorax in Lepidoptera is of great importance in their characterization. However, the thoracic morphology of Lepidoptera has been studied by only a few authors (Srivastava, 1961) and somehow not utilized in classification systems of the group because the structures of this tagma are of difficult preparation, visualization and understanding. Ackery et al. (1999) reported the Papilionidae as probably the best taxonomically documented family among all the others within Lepidoptera. The monophyly of the family is supported by a certain number of unique and universal autapomorphies, most of which are in the thorax (Ackery, 1984; Scoble, 1992).

The aim of this work was to study the external morphology of Heraclides anchisiades capys
(Hübner, [1809]), with the purpose of highlighting the components of the thorax and its appendages to compare with other Papilionoidea and Hesperioidea.

\section{MATERIAL AND METHODS}

The origin of the material, as well as the treatment of the structures, confection of the illustrations and elaboration of the photographical materials by scanning electronic microscope, followed the same methodology of the previous study about head and its appendages (Leite et al., 2010).

The wings were removed from the dry sample with forceps and scissors and then bleached in Petri plates, at first by putting in alcohol (70\%), then immersed in Sodium Hypochlorite $(\mathrm{NaOCl})$

*Author for correspondence: madison.2@ig.com.br 
until the total clearing, later submersed again in alcohol $(70 \%)$ and then removed and dried with absorbent paper.

For thorax structures, the terminology used followed mainly Srivastava $(1961 ; 1962)$ on his studies with Papilio demoleus Linnaeus, 1758 (Lepidoptera - Papilionidae), with modifications based on the several studies of morphology of Lepidoptera (Shepard, 1930; Madden, 1944; Casagrande, 1979c; Sorensen, 1980; Bilotta, 1994; Bizarro et al., 2003b; C. Mielke et al., 2004b).

\section{RESULTS}

\section{Prothorax}

The shortest among the three thoracic segments and mostly formed by membranous areas. Dorsally constituted by two distinct regions: anteriorly, the prozona and posteriorly, the postzona, separated by the interzonal suture. The prozonal region is ' $\mathrm{T}$ '-shaped, divided divided in transverse prozonal arm and longitudinal prozonal arm, separated by the transverse prozonal suture. The longitudinal prozonal suture crosses the longitudinal prozonal arm from the transverse prozonal suture to the interzonal suture. Postzona is ' $\mathrm{Y}$ '-shaped and presents, laterally the longitudinal postzonal suture on both sides. First spiracle posteroventrally to the postzona on the propleuron and dorsoposterior to the episternum I.

In lateral view, the episternum I is anteriorly and anteroventrally to this the basisternum I. Posteroventral trochantin to the episternum I joining it to the prothoracic coxa, which has differentiated bristles on the basal edge.

Ventrally the basisternum I, ' $T$ '-shaped and the spinal-basisternal pit I anteromedially. Laterally to the basisternum I, the episternum I is separated from the basisternum I by the sterno-pleural suture. The furca, posterior to the basisternum I, articulates on the posterior portion with the espinasternum I that is divided in a transverse arm of espinasternum I and longitudinal arm of espinasternum I, the latest with a wide shape and posteriorly with triangular shape. First spiracle on the margin of the propleuron and lateral to the episternum I.

\section{Mesothorax}

The biggest thoracic segment. In dorsal view the scutum II is narrower anteriorly, widening towards the scutellum II. Acrotergite as a narrow band anterior to the scutum II. Lateroanteriorly, the scutal suture II separates the scutum II from the suralare II and posteriorly the scutellum II separated from the scutum II by the scuto-scutellar suture II in the shape of a ' $W$ ', with a convex shape on both sides on the posterior edge, merging anteromedially on the scutum II. Posterior to the scutellum II, the triangular shaped postnotum II and the smallest within the mesothoracic sclerites. Laterally, the prescutum II anterior to the scutum II, and separated from it by the prescutum-scutal suture II, projects itself ventrally forming the prealare process II and posterior to it the extended subtegula with an upside down ' $L$ ' shape that reaches the pleural wing process II. Ventral to the subtegula, the basalare II totally round shaped. Tegula dorsolaterally as a movable lobe that articulates on the posterior region with the subtegula. Scutum II ventrally separated from the suralare II by the scutal suture II and suralare II curved towards the subalare II. Posterodorsal to the subalar II and as a posteroventral expansion of the scutum II, is the adnotale and posterior to it the posterior notal wing process II as a narrow ' $\mathrm{C}$ 'shaped structure. Axillary cord II ventral to the posterior region of the scutum II and supported on the lateroanterior extension of the scutellum II. Ventral and posterior to the axillary cord II, the postalar bridge extends itself to the postnotum II and, as a narrow band, dorsal to the axillary cord II the postalar bridge process arises.

Pleural region divided in two distinct regions: the proximal anterior episternum II and the distal posterior epimeron II, separated by the pleural suture II, suture that extends itself dorsal and longitudinally since the pleural wing process II to the coxo-pleural articulation II ventrally. Episternum II separated in anepisternum II and katepisternum II, located, respectively, dorsal and ventrally. The anepisternum II, a small oval structure posteriorly fused to the pleural wing process II and ventrally separated from the katepisternum II by the anepisternal suture II. Anterior to the katepisternum II and separated from the kapisternum II by the preepisternal suture II is the preepisternum II and posterior to it the epimeron II. On the anterodorsal portion of the epimeron II, a flap reaches the pleural wing process II and on the posterodorsal region reaches the ventral margin of the postalar brigde. Lateroposterior to the epimeron II, the second 
thoracic spiracle on the intersegmental membrane between the meso and metathorax.

In ventral and anterior view, the preepisternum II located laterally to the longitudinal arm of the espinasternum I. The preepisternal suture II separates posteriorly the preepisternum II from the katepisternum II and runs transversally on both sides, merging anteromedially to form the discrimen II, which extends longitudinally to the furcal pit II, forming an invagination of the sternum II. Yet anterior to the merge of the preepisternal suture II, a portion not invaginated of the sternum II in triangular shape.
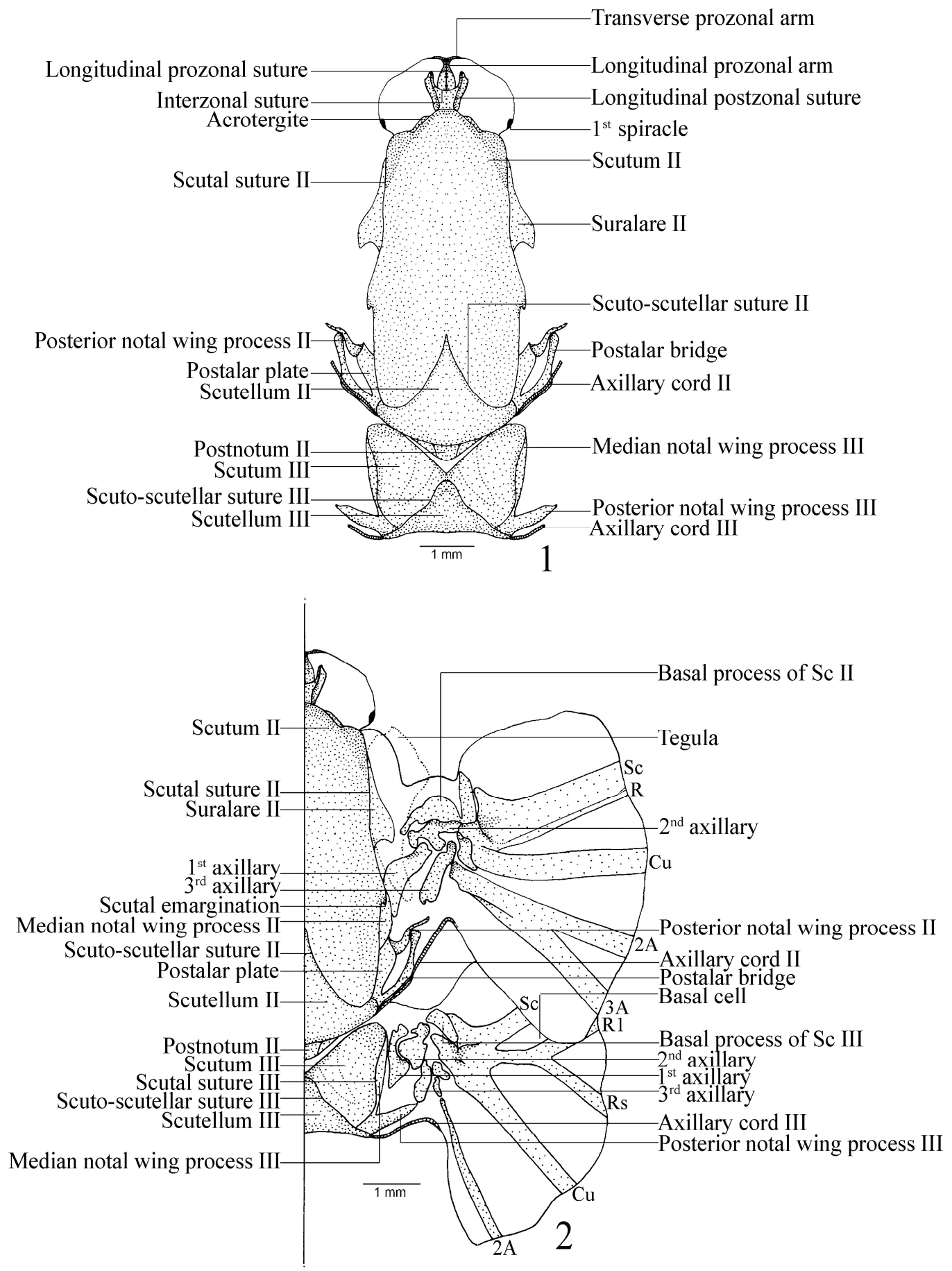

Figures 1 - 2 - Heraclides anchisiades capys: Thorax. 1 - dorsal view. 2 - dorsal view of the wing sclerites. 

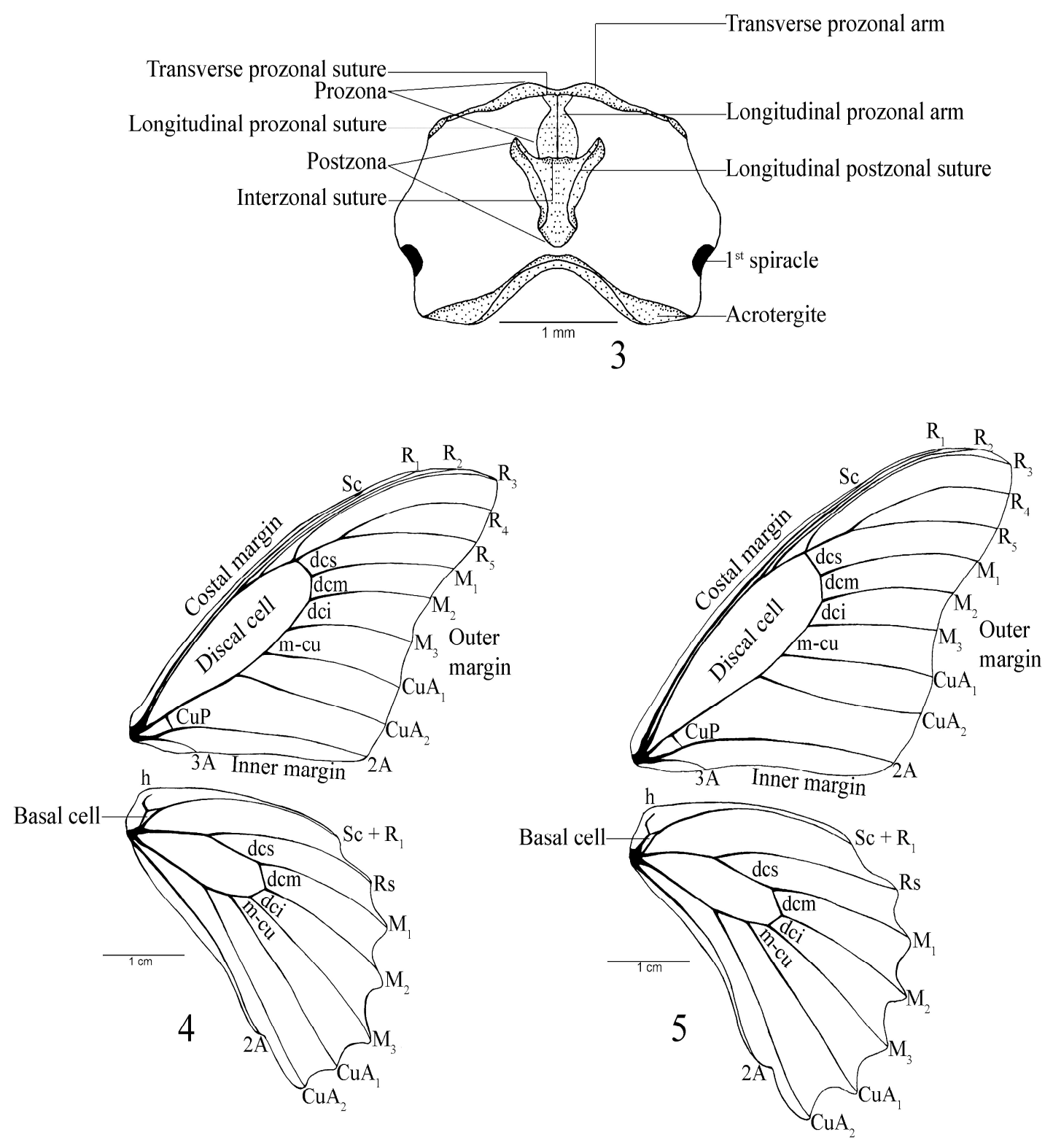

Figures 3 - 5 - Heraclides anchisiades capys: Thorax. 3 - dorsal view of the prothorax. 4 - 5 forewings and hindwings: 4 - male. 5 - female.

\section{Metathorax}

The second biggest thoracic sclerite. Dorsally divided in scutum III anteriorly and scutellum III posteriorly, separated by the scuto-scutellar suture III. Anterior to the scutum III, a membranous area that separates it from the postnotum II. Scutum III narrower medially, gradually extending towards the lateral edges, forming two subtriangular shaped areas. While the scutellum III, triangular shaped and smaller, is situated posteriorly.
Laterally the subquadrangular scutum III, ventrally separated from the suralare III by the scutal suture III, posteriorly separated from the subrectangular scutellum III by the scuto-scutellar suture III, the scutellum III extends dorsoventrally towards the posterior region of the posterior notal wing process III. Ventral to the scutellum III, supported on the axillary cord III and posteroventrally to it, the postnotum III is not visible dorsally. Subalare III, a narrow structure situated approximately in the center of the pleural membrane. 
Pleural region III with similar conformation to the pleural region II, but the basisternum II is situated anteroventrally to the katepisternum II, this is not observed on the mesothorax. Anterodorsally to the katepisternum III, the rounded basalare III, has a structure superimposed to the ventral margin called basalare III "pad", membranous and with several bristles dorsally. The epimeron III extends dorsoposteriorly to the anterior portion of the postnotum III.

In ventral view, the discrimen III extends mediolongitudinally from the anterior margin of the metathorax to the furcal pit III posteriorly. The basisternum III, lateral to the discrimen III, as a subrectangular plate.

\section{Thoracic appendages}

Presenting a couple of legs by thoracic segment, each one composed of coxa, trochanter, femur, tibia and tarsus. Prothoracic leg is the smallest amongst them. Coxa I elongated, wider on the basal edge and narrowing gradually in distal direction, it articulates with the pleuron through a "goblet"-shaped small sclerite, the trochantin. Coxal suture I extends from the base of the coxa I to approximately one fifth of its length. Subrectangular trochanter, the smallest among the sclerites of the leg. Tibia I presents medially, on its posterior surface, a foliaceous structure, the epiphysis. Tarsus I composed by five tarsomeres, the proximal being the biggest one, which is approximately four times the length of the others, that have similar lengths. Thorns are visualized in all the length of the tibia and tarsus, distributed in irregular form in the ventral surface of the tibia and of regular form forming two rows of thorns in the ventral surface of the tarsomeres. On the distitarsus, there is a distal formation of differentiated bristles situated ventrally among the thorns. Tarsal claws elongated, curved and intermediated basalventrally on the membrane by the unguitractor plate, of quadrangular shape.

Meso and metathoracic legs present similar conformation. Coxa II longitudinally divided in two parts by the coxal suture II, the eucoxa II anterior and the meron II posterior. Coxa III similar to the coxa II, however the meron III holds a transvere suture that divides it in two regions, the meral suture. A couple of spurs is articulated to the inner distal edge of the meso and metathoracic tibias.

\section{Wings and wing sclerites}

Triangular forewings on both sexes. Outer margin with the superior and inferior thirds of convex aspect, while the middle third is concave in the height of $M_{2}$ and $M_{3}$, this characteristic is more pronounced in females. Subcostal (Sc) starts at the axillary region, thicker on the base, ending near the costal margin on its distal third. Radial (R) appears joined and parallel to the Sc and when reaching the distal third of the discal cell forks into $R_{1}$ and $R s$ and subsequently, is divided in $R_{2}, R_{3}$, $\mathrm{R}_{4}$ and $\mathrm{R}_{5} ; \mathrm{R}_{3}$ ending at the apex and $\mathrm{R}_{4}$ and $\mathrm{R}_{5}$ on the outer margin. Costal and outer margins merge forming the apex of the wing, sharp in males and more rounded in females. On males $\mathbf{M}_{1}, \mathrm{M}_{2}$ and $\mathrm{M}_{3}$ arise separated from the top of the discal cell, $M_{2}$ nearer to $M_{1}$ and $M_{3}$ more distanced and curved downward towards the outer margin. On males dci is still lightly bigger than dcm. On females the veins dcm and dci of equal size and $M_{1}, M_{2}$ and $M_{3}$ equidistant from the base up to the outer margin. $\mathrm{CuA}_{1}$ and $\mathrm{CuA}_{2}$ start separated from the discal cell by a distance equivalent to extension of m-cu, on females $\mathrm{CuA}_{2}$ is curved upwards, which does not occur in males. Short $\mathrm{CuP}$ starting from the anterior third of the Cubital and reaching the anterior third of $2 \mathrm{~A} .2 \mathrm{~A}$ and $3 \mathrm{~A}$ veins start from the axillary region separated from the discal cell, 2A reaches the anal angle of the wing, nearer to the inner margin on males and more distant on females. 3A vein curved towards the inner margin and reaching it in the proximal third.

Hindwings convex on the costal and outer margins and concave on the inner margin. $\mathrm{Sc}+\mathrm{R}_{1}$ vein from the axillary region to the apex of the wing. Humeral vein $(h)$ curved towards the apex of the wing and appearing near $\mathrm{Sc}+\mathrm{R}_{1}$ on their base, where both are slightly separated to form the basal cell. dcs vein bigger than the dcm, which is bigger than dci. $\mathrm{CuA}_{1}$ e $\mathrm{CuA}_{2}$ start separately from the discal cell by a distance slightly bigger than the length of m-cu. $2 \mathrm{~A}$ vein, the only anal one, ends in the anal angle of the wing.

The sclerites of the wing represent the region that connects the wing to the thorax, constituted by several sclerites of irregular forms. On the forewing, lateroposterior to the scutum II, the postalar plate has anteriorly the median notal wing process II and anterolaterally the posterior notal 
wing process II, the first articulates to the first axillary and the second to the third axillary, on this last one the articulation happens through a fold of the membrane. Third axillary laterodistally articulated to the basal regions of the Cubital and the Anal. Second axillary distal to the first and the third, trilobated shaped, with the anterior lobe articulated to the first axillary, the median one to the third axillary and the posterior to the basal sclerites of Sc e R. Distally to the second axillary, the basal process of Sc II is articulated.

On the hindwings, the posterior notal process is lateroposteriorly to the scutellum III and distally articulated with the third axillary, the latest is lateroposteriorly articulated with the basal sclerites of the $2 \mathrm{~A}$ vein and distally with the second axillary. The first axillary articulates with the second axillary laterally and the latest is distally articulated with the basal process of Sc III.

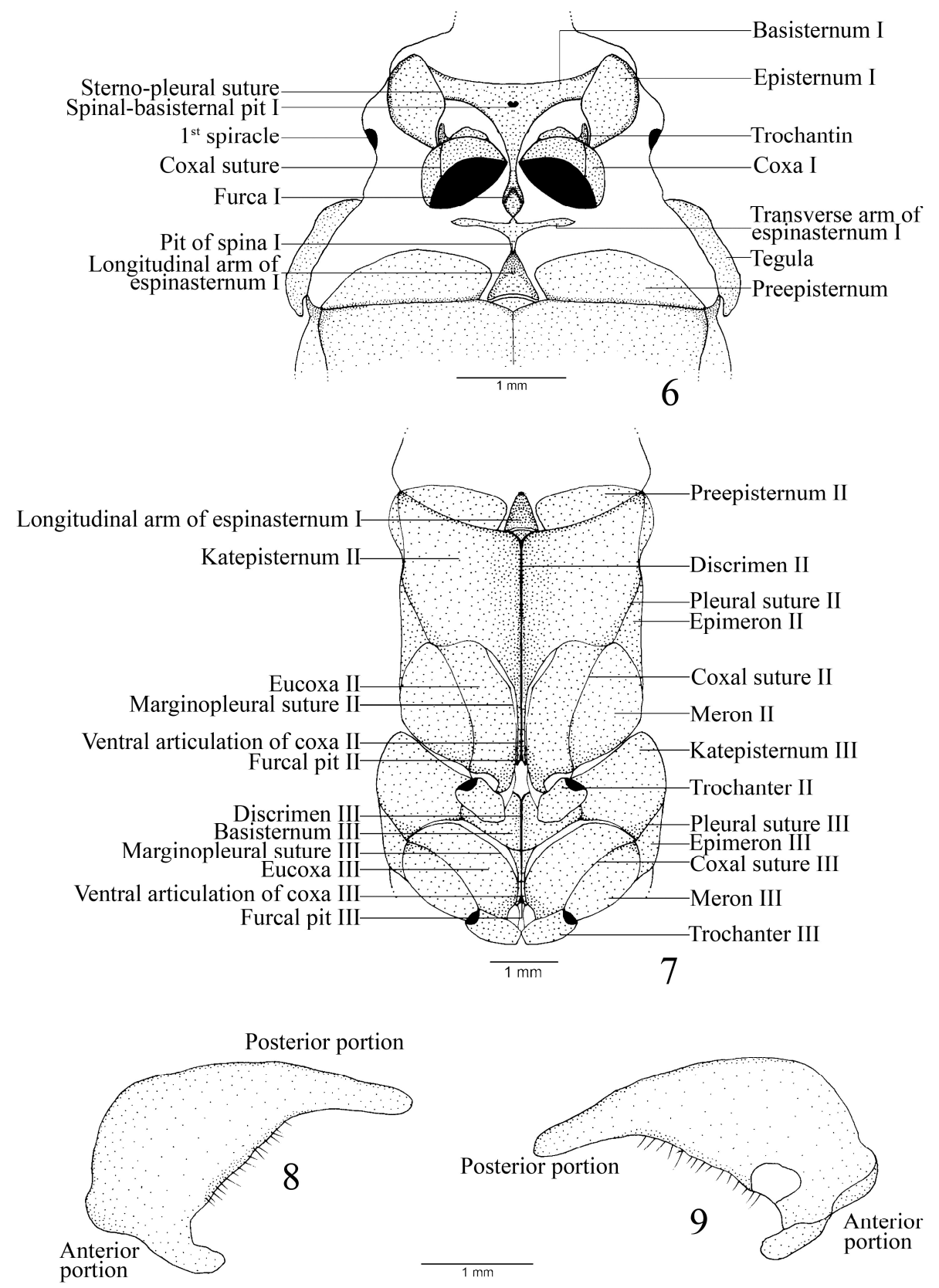

Figures 6 - 9 - Heraclides anchisiades capys: Thorax. 6 - ventral view of the prothorax. 7 - ventral view of meso and metathorax. 8 - 9 - tegula: 8 - anterior view. 9 - posterior view. 


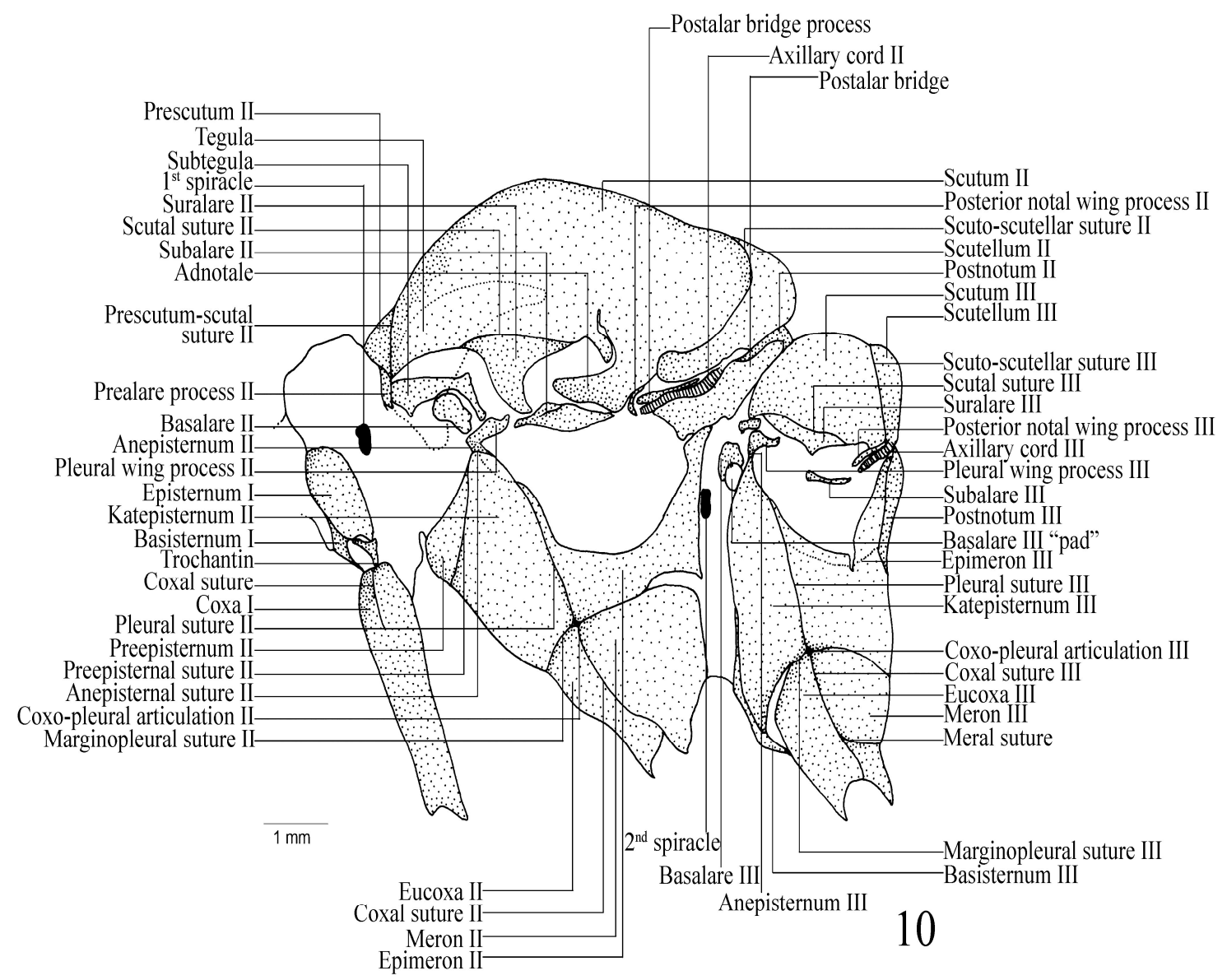

Figure 10 - Heraclides anchisiades capys: Lateral view of the thorax.

\section{DISCUSSION}

Males and females do not present significant differences regarding the thoracic structures, with the exception of the format of the wings.

The pronotum presents a membranous patagia, and as observed by Ehrlich (1958b) its delimitation on the pronotal area is not possible, as in Papilio demoleus L., (Srivastava, 1961). In other Papilionoidea, the patagia is evident and anterodorsally sclerotized on the pronotum (Ehrlich, 1958a; Casagrande, 1979c; Sorensen, 1980; Bilotta, 1994; C. Mielke et al., 2004b).

The trochantin as a small sclerite distal to the coxa $\mathrm{I}$, is present in some groups of Papilionoidea (Srivastava, 1961; C. Mielke et al., 2004b), and in others (Ehrlich, 1958a; Casagrande, 1979c;
Sorensen, 1980; Bizarro et al., 2003b) absent or not referenced to.

On the forewing, $3 \mathrm{~A}$ is present in common origin with $2 \mathrm{~A}$ and reaches the inner margin of the wing on its proximal third. In some groups of Papilionoidea, 3A is absent (Ehrlich, 1958a; Casagrande, 1979c; Bilotta, 1994; C. Mielke et al., 2004b). In other representatives of this superfamily, it appears on the forewing, but curved upwards and ends when it reaches the proximal third of 2A (Sorensen, 1980; Bizarro et al., 2003b; Duarte, 2007). In Hesperioidea Ehrlich (1960) studied Epargyreus clarus (Cramer, 1775) (Lepidoptera - Hesperiidae) and identified the presence of $3 \mathrm{~A}$, curved downwards and flawed when reaching the inner margin of the wing. 


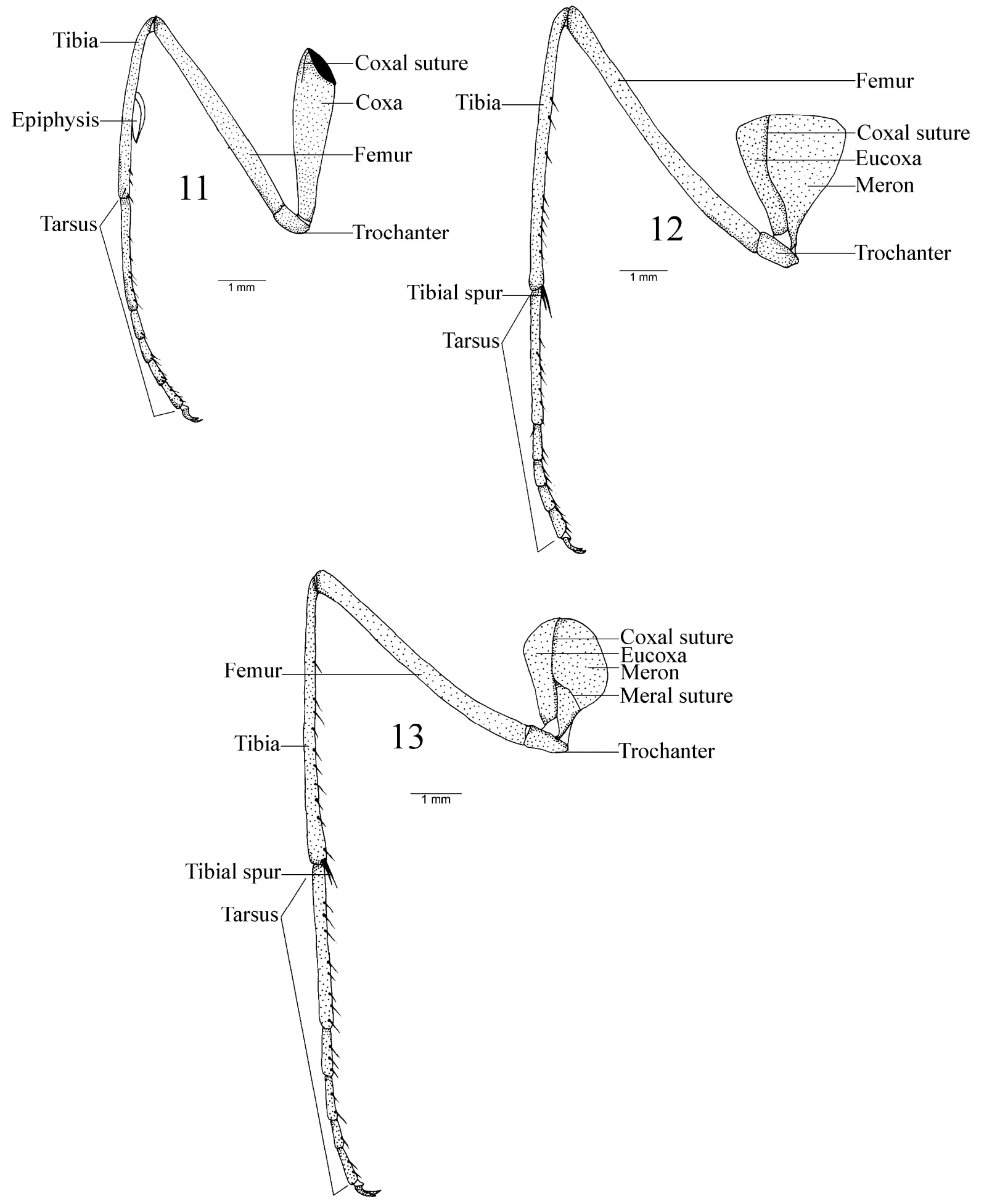

Figures 11 - 13 - Heraclides anchisiades capys: Legs. 11 - prothoracic. 12 - mesothoracic. 13 metathoracic. 

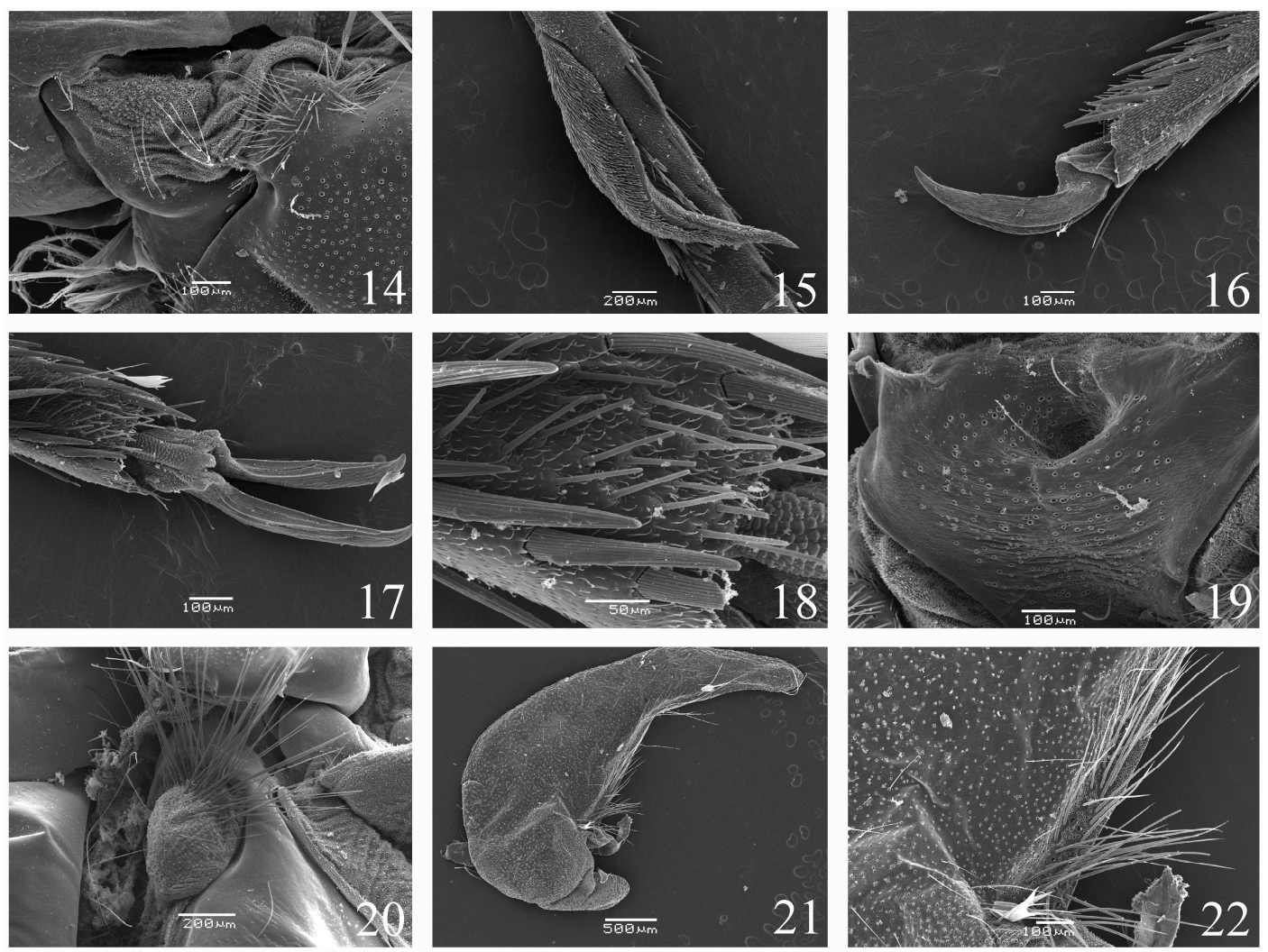

Figures 14 - 22 - Heraclides anchisiades capys: 14 - trochantin. 15 - 18 - prothoracic leg: 15 epiphysis. 16 - lateral view of the distitarsus. 17 - ventral view of the distitarsus. 18 - bristles of the distitarsus. 19 - basisternum I. 20 - basalare III "pad". 21 - 22 - tegula: 21 - general view. 22 - view of the bristles.

Srivastava (1962) observed a different arrangement of the axillary sclerites of the forewing from the one verified in this study. In Papilio demoleus L., the first axillary articulates anteriorly with the suralare II and the second axillary anteriorly with median notal wing process II. In Heraclides anchisiades capys, the first axillary articulates with the median notal wing process II and the second axillary, distally to the first, does not make any connection with the suralare II. A marginal suture observed by Srivastava (1962), parallel to the anterior margin of the suralare II on Papilio demoleus, is not visualized in the studied specie.

$2 \mathrm{~A}$ vein is the only anal one present on the hindwing as in Papilio demoleus Srivastava (1962). In other Papilionoidea and Hesperioidea documented to the present date, the $3 \mathrm{~A}$ vein is also found on the hindwing.

On the metathoracic coxa, the meron is transversally divided in two regions by the meral suture, this suture was already described for Papilionidae Ehrlich (1958b) and observed on Papilio demoleus by Srivastava (1962). There are no accounts of this structure for other Papilionoidea and Hesperioidea.

Metathoracic tibia with only a pair of tibial spurs as well as the other Papilionoidea and opposite to what was verified in many Hesperioidea, with two pairs of spurs as cited by (Ehrlich, 1960).

Anterodorsally to the katepisternum III, ventrally to the basalare III and supporting it, the basalare III "pad", as a membranous structure with bristles distributed on the dorsal surface. In Lycaenidae (Sorensen, 1980; Duarte, 2007) the basalare III "pad" is also cited, as well as in Papilio demoleus by Srivastava (1962) and by Madden (1944) for Sphingidae. This structure is completely absent on other Papilionoidea and Hesperioidea studied to date. 


\section{ACKNOWLEDGMENTS}

We acknowledge the assistance of the Center of Electronic Microscopy of the Universidade Federal do Paraná for the elaboration of the photographical materials.

\section{RESUMO}

O propósito deste estudo foi evidenciar os componentes morfológicos do tórax e seus apêndices nos adultos de Heraclides anchisiades capys (Hübner, [1809]), visando um enfoque comparativo com outros Papilionoidea e Hesperioidea. A morfologia é descrita com ilustrações e fotografias em microscópio eletrônico de varredura. Dentre os caracteres morfológicos encontrados, destacam-se: patágia membranosa no protórax, anepisterno II fusionado ao processo pleural da asa II como um pequeno esclerito dorsal ao catepisterno II; 3A presente na asa anterior, alcançando a margem interna em seu terço proximal; presença de "almofada" do basalar III e sutura meral na coxa III

\section{REFERENCES}

Ackery, P. R. (1984), Systematic and faunistic studies on butterflies, pp. $9-21,1$ fig. In: Vane-Wright, R. I. and P. R. Ackery (Eds.). The Biology of Butterflies, Academic Press, 429 pp.

Ackery, P, R.; De Jong R. and Vane-Wright R. J. (1999), The Butterflies Hydeloidea, Hesperioidea and Papilionoidea, p. 263 - 300. In: P. N. Kristensen (Ed.). Band/Volume IV Arthropoda: Insecta. Teilband / Part 35. Lepidoptera moths and butterflies: evolution, systematics and biogeography. Vol. 1, X+491p. In: M. Fischer (Ed.). Handbook of Zoology, Berlin, New York, Walter de Gruyter.

Bilotta, I. G. (1994), Morfologia comparada do tórax das espécies sulbrasileiras de Morphinae (Lepidoptera: Nymphalidae). Rev Bras Zool, 11 (4), $691-713$.

Bizarro, J. M. S.; Casagrande, M. M. and Mielke, O. H. H. (2003), Morfologia externa de Thyridia psidii cetoides (Rosenberg and Talbot) II. Tórax e apêndices (Lepidoptera, Nymphalidae, Ithomiinae). Rev Bras Zool, 20 (3), 419 - 425.

Casagrande, M. M. (1979), Sobre Caligo beltrao (Illiger). III: Morfologia externa do adulto - tórax. (Lepidoptera, Satyridae, Brassolinae). Rev Bras Biol, 39 (2), 347 - 355.
Duarte M. (2007), Morfologia externa do adulto de Hemiargus hanno (Stoll) (Lepidoptera, Lycaenidae, Polyommatinae, Polymmatini) II. Região cervical, tórax e abdome. Iheringia, Sér Zool, 97 (2), 194 206.

Ehrlich, P. R. (1958), The integumental anatomy of the monarch butterfly Danaus plexippus L., (Lepidoptera: Danaidae). Univ Kans Sci Bul, 38, 1315 - 1349.

Ehrlich, P. R. (1958), The comparative morphology, phylogeny, and the higher classification of the butterflies (Lepidoptera, Papilionoidea). Univ Kans Sci Bull, 39, 305 - 370.

Ehrlich, P. R. (1960), The integumental anatomy of the silver-spotted skipper, Epargyreus clarus (Cramer, 1775) (Lepidoptera $\quad-\quad$ Hesperiidae). Microentomology, 24, 1 - 23.

Leite, L. A. R; Casagrande, M. M. and Mielke, O. H. H. (2010). External Morphology of the Adult of Heraclides anchisiades capys (Hübner, [1809]) (Lepidoptera - Papilionidae). I. Head, cephalic appendages and cervical region. Braz Arch Biol Techn, 53 (5), 1119 - 1126.

Madden, A. H. (1944), The external morphology of the Tobacco Hornworm (Lepidoptera, Sphingidae). Ann Entomol Soc Am, 37, 145 - 160.

Mielke, C. G. C.; Mielke, O. H. H. and Casagrande, M. M. (2004), Estudo comparado da morfologia externa de Zaretis itys itylus (Westwood) e Agrias claudina anneta (Gray) (Lepidoptera, Nymphalidae, Charaxinae). II. Tórax e apêndices. Rev Bras Zool, 21 (3), $421-433$.

Scoble, M. J. (1992), The Lepidoptera: form, function and diversity. Natural History Museum Publications. Oxford University Press, 404p.

Shepard, H. (1930), The pleural and sternal sclerites of the Lepidopterous thorax. Ann Entomol Soc Am, 23, $237-260$.

Sorensen, J. T. (1980), An integumental anatomy for the butterfly Glaucopsyche lygdamus (Lepidoptera: Lycaenidae): a morphological terminology and homology. Zool J Linn Soc-Lond, 70, 55 - 101.

Srivastava, K. P. (1961), Studies on the lemon butterfly Papilio demoleus L. (Lepidoptera). II Skeleto muscular mechanism (cervix and prothorax). Indian J. Ent, 23, 202 - 213.

Srivastava, K. P. (1962), Studies on the lemon butterfly Papilio demoleus L. (Lepidoptera). III Skeleto muscular mechanism (pterothorax and its legs). Indian J. Ent, 24, 114 - 134. 